\title{
Awards Presented at the 51st Annual Meeting of the BEHAVIOR GENETICS ASSOCIATION Tuesday, June 29, 2021
}

C Springer Science+Business Media, LLC, part of Springer Nature 2021

The 44th Annual Thompson Award for the best oral presentation by an associate member was awarded to Evan J. Giangrande from the University of Virginia for his presentation "Biometric analysis of within-person Flynn effects".

The 9th Annual Rowe Award for the best poster presentation by an associate member was awarded to Evan Winiger of the University of Colorado for his presentation "Genetic Identification of Sleep Vulnerabilities Inherited with Substance Use".

The 21st Annual Fulker Award for the outstanding paper in Behavior Genetics during the past year was presented to Justin Tubbs, Robert Porsch, Stacey Cherny, Pak Sham for their work “The Genes We Inherit and Those We Don't: Maternal Genetic Nurture and Child BMI Trajectories" by John Hewitt.

The 17th Annual Fuller and Scott Award for outstanding early career contributions to the field was presented to Abdel Abdellaoui and Kristine Marceau by Tinca Polderman and Valerie Knopik.

The Federation of Associations in Behavioral and Brain Sciences (FABBS) Early Career Impact Award was presented to Kristine Marceau by member-at-large Paige Harden.

The 43rd annual Dobzhansky Award for outstanding lifetime contributions to the field of behavior genetics was presented to Laura Baker by Past-President Jenae Neiderhiser.

Respectfully submitted,

Sarah Medland

Secretary, Behavior Genetics Association

Jenae Neiderhiser

Past President, Chair of the BGA Awards Committee

Publisher's Note Springer Nature remains neutral with regard to jurisdictional claims in published maps and institutional affiliations. 